\title{
Skojarzenia słowne osób dwujęzycznych na podstawie języków: polskiego i włoskiego
}

\section{Word associations of bilingual speakers of the languages: Polish and Italian}

\author{
Michalina Lach, Michat Nowak \\ Instytut Językoznawstwa, Uniwersytet im. Adama Mickiewicza \\ ul. Międzychodzka 5, 60-371 Poznań
}

\begin{abstract}
This article is an attempt to explain the basic rules of word associacions of bilingual speakers as well as the matter of the second language acquisition with its cultural implications. The paper deals also with the matter of lexical access with particular stress put on the theory of connectionism. The study is based on the free word association test and was conducted with cooperation with a group of Polish students of the Italian language. The results show a significant correlation between learning a second language and acquiring the culture of its geographic area.
\end{abstract}

\section{Wstęp. Badanie skojarzeń słownych}

Testy asocjacyjne mają szeroki zakres zastosowań. Używane są od lat jako narzędzie diagnostyczne $\mathrm{w}$ badaniach dotyczących przetwarzania informacji w umyśle, czyli szeroko pojętego kognitywizmu. Wykorzystuje się je również do oceny inteligencji, rozwoju i różnic kompetencji językowej w zakresie jednego języka używanego przez osoby o różnym poziomie wykształcenia i pochodzenia (społecznego), a także $\mathrm{w}$ badaniach dotyczących różnic typologicznych pomiędzy językami (Łobacz, Mikołajczak-Matyja 2002). Także stopień biegłości w L2 może zostać odzwierciedlony w wynikach takiego testu. Schmitt (1998) pisze o stopniu znajomości L2 porównywalnym do kompetencji językowej rodzimego użytkownika danego języka, określanym za pomocą właśnie testów skojarzeniowych. Jednak późniejsze badania Woltera (2002) dowodza, że obecna forma testów skojarzeniowych jedynie w nieznacznym stopniu odzwierciedla faktyczną znajomość języka drugiego. Nie dyskwalifikuje to jednak tej metody badawczej, a jedynie jest pewnym wyznacznikiem kierunku rozwoju tego typu badań. Mimo że test skojarzeniowy skupia się głównie na leksykonie umysłowym i na nim operuje, daje wiele interesujących możliwości interpretacji wyników, począwszy od różnic między językami, poprzez spojrzenie na język jako narzędzie wyrażania własnych myśli, aż po odkrywanie nawyków językowych i cech kulturowych.

Wydaje się niemożliwe, że podmiot uczący się języka drugiego może pozostać obojętny na wpływ kultury danej grupy językowej (por. Scheu 2000). Bilingwizm ułatwia kontakty międzyludzkie, buduje pozytywne nastawienie interkulturowe, sprzyja większej tolerancji, akceptacji i zrozumieniu innych. W rozmyślaniach nad naturą dwujęzyczności nasuwa się pytanie, do jakiego stopnia werbalne zachowanie osób dwujęzycznych odzwierciedla ich dwukulturowość. 
Ponieważ jednak język pierwszy nabywany jest bardzo wcześnie, trudno sobie zazwyczaj uświadomić, jaki ma on wpływ na wiele aspektów zachowania, np. na proces myślenia, na to, co jest tematem tego procesu, na postrzeganie i analizę świata, czy na sposób interakcji. Mimo podświadomego zachowania nabywanego razem $\mathrm{z}$ L1, wraz $\mathrm{z}$ rozwinięciem umiejętności posługiwania się językiem L2, podmiot zyskuje zintegrowaną dwukulturową tożsamość, a co za tym idzie - dwa oddzielne sposoby odnoszenia się do otoczenia, jak również dwa różne zestawy cech charakterystycznych dla każdej z kultur. Bycie dwukulturowym wiąże się bowiem z procesem internalizacji dwóch kultur, które kierują odczuciami, myślami i działaniami jednostki (RamirezEsperanza, Gosling, Benet-Martinez, Potter, Pennebaker 2004). Język ojczysty pełni zasadniczą rolę w kształtowaniu struktury osobowości i tożsamości (Czykwin 2002). Język i kultura determinują postrzeganie rzeczywistości. Co więcej, kształtują również pewne cechy psychiczne i warunkują sposoby reagowania typowe dla danej społeczności i jednostki. Coraz częściej mówi się, że osoby dwujęzyczne charakteryzuje inny zespół cech osobowościowych w zależności od języka, w którym w danym momencie mówią. Badacze wyjaśniają to zjawisko procesem Cultural Frame Switching (zmiany ramy kulturowej) (Ramirez-Esperanza, Gosling, Benet-Martinez, Potter, Pennebaker 2004: 100), podczas którego osoby dwujęzyczne (dwukulturowe) dostosowują wartości i cechy do bodźców ważnych dla kultury obszaru, którego językiem w danej chwili się posługują. Możliwym wyjaśnieniem tego procesu jest fakt, że język używany w danym momencie przywołuje właściwe dla danej kultury wartości, wspomnienia, doświadczenia. Zatem, kiedy osoba dwujęzyczna odpowiada $\mathrm{w}$ danym języku, odzwierciedla to jej postawy związane właśnie $\mathrm{z}$ tym językiem. Badania oparte na wypełnianiu ankiet $w$ dwóch znanych respondentom językach potwierdzają, że osoby takie charakteryzują się nieco innym zestawem cech osobowościowych w zależności od języka. Różnice w takich wymiarach jak np.: otwartość, serdeczność, sumienność czy wrażliwość, podkreślają fakt, że różne kultury cenią sobie inne cechy i użytkownicy innych języków będą kultywowali inne wartości (Ramirez-Esperanza, Gosling, Benet-Martinez, Potter, Pennebaker 2004). Wygodnym narzędziem do badania różnic kulturowych znajdujących odzwierciedlenie w języku jest test wolnych skojarzeń wyrazowych. Korshuk w swoim artykule (2004) powołuje się na słowa psycholingwistów Osgooda i Sebeoka (1965), którzy słusznie zauważyli, że słowa o wysokiej częstotliwości występowania w danej kulturze szybciej pojawiaja się jako reakcja na bodziec słowny niż te o niskiej częstotliwości. Co więcej, badacze tego problemu zgodnie twierdzą, że pewne czynniki kulturowe silnie wpływają na stereotypy skojarzeniowe. Nasuwa się oczywisty wniosek, że skoro język jest odzwierciedleniem kultury, analogicznie połączenia między wyrazami (między bodźcem a reakcją) odzwierciedlają pewne wzorce kulturowe. Jeśli na przykład na bodziec szacunek padnie odpowiedź starszy człowiek, można założyć, że respondent został wychowany w społeczeństwie ceniącym i szanującym wartość wieku. Co więcej, samo użycie danego języka może powodować taką reakcję skojarzeniową (Korshuk 2004).

Istotny dla badań omawianych $\mathrm{w}$ niniejszej publikacji jest test Kent-Rosanoffa. Przeprowadzony po raz pierwszy w 1910 roku z udziałem grupy 1000 osób (respondentów) w USA składa się ze 100 słów-bodźców. Są to hasła uznane przez Grację Kent i A.J. Rosanoffa za najczęściej występujące w potocznym języku angielskim (Kurcz 1967). Nie jest to bez znaczenia, gdyż właśnie takie słowa będą miały najsilniejsze powiązania z innymi leksemami. To właśnie na tej zasadzie buduje się normy skojarzeniowe dla określonych grup osób. Tym lepiej odzwierciedlają one pewne określone tendencje pojawiające się czy zanikające w języku, im większa jest próba takiego testu. Bardzo ważne jest również określenie cech właściwych dla takiej grupy. Należy więc spodziewać się różnych wyników dla grup dzieci i dorosłych, a w przypadku tych ostatnich również takie czynniki jak wiek, wykształcenie, czy pochodzenie mają wpływ na rodzaj reakcji (Ciechanowicz 1975).

Skojarzenie swobodne to połączenie między wyrazami (leksemami) na podstawie podobieństwa, kontrastu czy styczności elementów językowych (Ciechanowicz 1975 za: Brown). Niektóre źródła podają, że pokrewieństwo dwóch leksemów może być wyznaczane przez częstość występowania tych leksemów w swoim sąsiedztwie (Mikołajczak-Matyja 2004 za: Deese, Hörmann, Harley i in.). Są to niektóre z założeń stosunkowo młodego nurtu w psycholingwistyce zwanego konekcjonizmem. Model dostępu leksykalnego, będący jego częścią, opiera się przede 
wszystkim na skojarzeniach (asocjacjach). Mówi się o istnieniu tzw. węzłów (nodes) i łuków (Waring 1996). System leksykalny w założeniach tego modelu jest strukturą składającą się z wielu połączeń między węzłami. Model ten zakłada istnienie pod-sieci, które razem tworzą całość słownika umysłowego (Gleason, Ratner 2005). I tak, pewna część struktury leksykonu odpowiedzialna jest za aktywność węzłów związanych z kształtem fonologicznym, aktywacja innych powoduje powiązanie ze znaczeniem, jeszcze inna odpowiedzialna jest za powiązania danego leksemu z innymi leksemami, itd. System ten pozwala na magazynowanie informacji różnego typu w taki sposób, by ich przywołanie nie wiązało się z dużą utratą czasu. Leksemy, które używane są częściej - przez wzgląd na występowanie w różnych kontekstach - mają zwykle bardzo gęstą sieć połączeń z innymi węzłami. Na te leksemy, które używane są rzadziej czas reakcji jest zdecydowanie dłuższy, ponieważ dostęp do nich jest możliwy tylko dzięki ograniczonej liczbie połączeń. Wspomniana tu ilość połączeń stanowić też będzie o wiedzy jednostki dotyczącej danego leksemu - im połączeń jest więcej, tym wiedza jest obszerniejsza, a czas jej przechowywania (w pamięci LTM) jest dłuższy (Waring 1996).

Analiza badań opierających się na skojarzeniach swobodnych może dotyczyć trzech podstawowych zagadnień: częstości (powszechności) reakcji, czasu reakcji oraz klasyfikacji skojarzeń (Ciechanowicz 1975). Jeżeli zaś chodzi o skojarzenia osób dwujęzycznych, można mówić o porównaniu wyników takiego testu przeprowadzonego w dwóch wersjach językowych.

Obecnie, badania asocjacyjne są wiarygodną metodą badawczą. Istnieje wiele publikacji opierających się na tego typu badaniach, a które dotyczą właśnie norm skojarzeniowych i ich znaczenia dla badania rozwoju językowego, zarówno w sensie nabywania języka przez jednostkę (ontogeneza), jak i jego filogenezy, czyli zmian następujących wskutek rozwoju (ewolucji) języka (por. Ciechanowicz 1975; Kurcz 1967; Rosenzweig 1961a).

\section{Cel i metoda badań, materiał badawczy i respondenci}

Jak już wspomniano wcześniej, badania asocjacyjne, szczególnie dotyczące dużych grup badanych, dostarczają informacji o normach skojarzeniowych. Jak wiadomo, normy takie mogą ulegać zmianom w czasie (w przypadku norm określanych dla jednego języka j (por. Kurcz 1967; Rosenzweig 1961a). Co więcej, wyznaczanie norm dla różnych języków daje możliwość porównywania pewnych aspektów ich struktury. W ten sposób pojawiają się nowe możliwości wykorzystania testów o charakterze psycholingwistycznym dla celów socjologicznych i socjolingwistycznych, mianowicie badań podobieństw i różnic w postrzeganiu rzeczywistości poprzez język w zależności od kręgu kulturowego czy pochodzenia osoby badanej. W przypadku tego typu badań należy jednak zwrócić uwagę na to, że nawet niewielkie rozbieżności w thumaczeniach treści testu skojarzeniowego mają znaczący wpływ na ich wyniki (Kurcz 1967).

Poza wyznaczaniem norm skojarzeniowych, niewątpliwą zaletą testów asocjacyjnych jest ich wgląd w strukturę leksykonu umysłowego. Testy tego typu pozwalają ustalić, przynajmniej do pewnego stopnia, relacje, jakie zachodzą między poszczególnymi leksemami, ich „ułożenie” i dostęp leksykalny. Poza tym, jeśli nauka języka L2 implikuje przyswojenie kultury obszaru, dla którego ten język jest rodzimy, należałoby rozważyć, czy osoby dwujęzyczne (podobnie w przypadku osób wielojęzycznych) są też dwu (wielo-) kulturowe.

Ze względu na swój charakter, wyniki testów asocjacyjnych mogą być analizowane zależnie od potrzeb badacza. Przeprowadzone badania poświęcone zostały skojarzeniom słownym osób bilingwalnych w zakresie języków: polskiego (język pierwszy, L1) oraz języka włoskiego (L2). Miały one na celu ukazać, w jakim stopniu zakres i charakter skojarzeń w języku polskim, ustalone na podstawie testów asocjacyjnych przeprowadzonych z udziałem opisanej niżej grupy studentów, są odzwierciedlone w analogicznych badaniach dla języka włoskiego. Innymi słowy: czy istnieją a jeśli tak, to jakie, zależności między rodzajem skojarzeń osób dwujęzycznych w L1 i L2. Zajęto się również zagadnieniem związanym z dwukulturowością, tzn.: problemem uczenia się (nabywania) kultury obszaru językowego L2 wraz z uczeniem się języka L2.

Materiał badawczy wykorzystany do eksperymentu został oparty częściowo na liście KentRosanoffa oraz słownictwie tematycznie związanym z programem nauczania praktycznego języka włoskiego na uniwersytetach w Poznaniu i w Warszawie. Zwrócono uwagę na to, aby tłumaczenia 
słów bodźców były jak najbliższe znaczeniowo w obu językach. Gotowa lista składała się ze 108 słów-bodźców. 56 haseł zostało wybranych losowo z listy Kent-Rosanoffa:

$\begin{array}{lll}\text { ulica } & \text { tytoń } & \text { krzesło } \\ \text { ser } & \text { zielony } & \text { źółty } \\ \text { chleb } & \text { marzyć } & \text { pamięć } \\ \text { wysoki } & \text { wygoda } & \text { szybki } \\ \text { praca } & \text { czarny } & \text { młotek } \\ \text { gorzki } & \text { owoce } & \text { rozkaz } \\ \text { ziemia } & \text { chłopak } & \text { złodziej } \\ \text { gładki } & \text { czerwony } & \text { muzyka } \\ \text { radość } & \text { igła } & \text { lew } \\ \text { ciężki } & \text { miękki } & \text { dziecko } \\ \text { rzeka } & \text { głodny } & \text { ocean } \\ \text { piękny } & \text { kłopot } & \text { zdrowie } \\ \text { okno } & \text { powolny } & \text { twardy } \\ \text { szorstki } & \text { złość } & \text { kapusta } \\ \text { ciemny } & \text { król } & \text { pragnąć } \\ \text { choroba } & \text { krótki } & \text { motyl } \\ \text { kobieta } & \text { ręka } & \text { pająk } \\ \text { głęboki } & \text { łóżko } & \text { niebieski } \\ \text { dom } & \text { zimny } & \end{array}$

Drugą część listy stanowiły 52 hasła związane z dziedzinami omawianymi na praktycznych zajęciach języka włoskiego: religia, narodem i polityka, architektura, kulturą i sztuka, kuchnia, człowiekiem, otoczeniem i sportem. Wymienione tu kategorie opierają się na sylabusach zajęć. Celem użycia tej listy było sprawdzenie, czy wyrażenia należące do jednej kategorii semantycznej (np. powiązane $\mathrm{z}$ religią lub sportem) będą wywoływać podobne skojarzenia nabyte $\mathrm{w}$ procesie przyswajania pewnego zakresu materiału. Poza tym, oparta na sylabusach lista wyrażeń miała dawać gwarancję, że są one dobrze znane, a więc mają silnie utrwalone skojarzenia (jeśli nie semantyczne, to kulturowe lub stereotypowe). Wybrane hasła-bodźce to:

$\begin{array}{lll}\text { religia } & \text { telewizor } & \text { rodzina } \\ \text { święty } & \text { obraz } & \text { instynkt } \\ \text { krzyż } & \text { wystawa } & \text { płeć } \\ \text { anioł } & \text { most } & \text { ciało } \\ \text { grzech } & \text { sztuka } & \text { sąsiad } \\ \text { niebo } & \text { zabytek } & \text { miłość } \\ \text { naród i polityka } & \text { rzeźbić } & \text { wspólnie } \\ \text { zjednoczony } & \text { kultura } & \text { drzwi } \\ \text { naród } & \text { gwiazda } & \text { podłoga } \\ \text { solidarność } & \text { kuchnia } & \text { słońce } \\ \text { wojna } & \text { piwo } & \text { sport } \\ \text { flaga } & \text { jeść } & \text { kibic } \\ \text { godło } & \text { wino } & \text { wynik } \\ \text { granica } & \text { pachnący } & \text { amator } \\ \text { głosować } & \text { kawa } & \text { gwizdać } \\ \text { ojczyzna } & \text { makaron } & \text { mistrz } \\ \text { terroryzm } & \text { woda } & \text { piłkarz } \\ \text { architektura, kultura i } & \text { kolacja } & \text { wygrywać } \\ \text { sztuka } & \text { człowiek, otoczenie } & \text { piłka } \\ \text { reklama } & \text { ojciec } & \end{array}$


Warto dodać, że część słownictwa listy Kent-Rosanoffa, a także słownictwa opartego na tematyce zajęć praktycznych z języka włoskiego pokrywały się ze sobą. Wynika to z powszechności słownictwa listy słów Kent-Rosanoffa, które w dużej mierze należy do podstawowego zasobu słów każdego użytkownika języka, w tym wypadku zarówno leksykonu języka L1, jak i L2.

Kolejność ułożenia haseł w listach polskiej i włoskiej była losowa i różna dla każdej z list. Miało to na celu uniknięcie pojawienia się sytuacji, w której badany odtwarzałby z pamięci układ poszczególnych bodźców (fragmentów list), co mogłoby sprzyjać torowaniu (pomimo około czterotygodniowej przerwy pomiędzy badaniami). Po przeprowadzeniu testów wypełnione ankiety dobrano w pary, tak, aby komplet taki zawsze był autorstwa jednej i tej samej osoby.

W badaniach wzięli udział studenci studiów dziennych trzeciego i piątego roku filologii włoskiej Uniwersytetu im. Adama Mickiewicza w Poznaniu oraz studenci studiów dziennych i wieczorowych trzeciego roku filologii włoskiej Uniwersytetu Warszawskiego. Okres nauki języka włoskiego wynosił co najmniej trzy lata. Średnia wieku osób ankietowanych wynosiła 23 lata. Grupa ankietowanych osób, mimo że składała się ze studentów dwóch uniwersytetów różnych miast, była grupą dość jednorodną. Oznacza to, że w badaniach wzięli udział studenci, a więc osoby charakteryzujące się pewnym określonym zbiorem cech osobowych (mowa tutaj o stereotypowym profilu studenta) oraz należące do określonego przedziału wiekowego, ale co ważniejsze - byli to studenci kierunku filologicznego. Jak wiadomo, charakter studiów filologicznych opiera się przede wszystkim na traktowaniu języka jako środka komunikacji, kładąc szczególny nacisk na jego rozwój, w tym rozbudowanie słownika. Spodziewano się zatem, że eksperyment skojarzeniowy przeprowadzony $\mathrm{z}$ udziałem takiej grupy respondentów będzie charakteryzować się szerokim zakresem reakcji leksykalnych.

Tabela 1. Zestawienie ilościowe uzyskanego materiatu (ankiety w języku polskim $i$ włoskim).

\begin{tabular}{|c|c|c|c|c|c|}
\hline & $\begin{array}{c}\text { UAM } \\
\text { rok III i V } \\
\text { (tryb dzienny) } \\
\text { (Lista włoska: marzec / } \\
\text { kwiecień 2006r.; } \\
\text { Lista polska: kwiecień / maj } \\
\text { 2006r.) }\end{array}$ & $\begin{array}{c}\text { UW } \\
\text { rok III } \\
\text { (tryb dzienny i wieczorowy) } \\
\\
\text { (Lista włoska: maj 2006r; } \\
\text { Lista polska: czewiec 2006r.) }\end{array}$ & 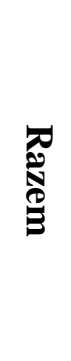 & 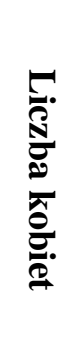 & ב.: \\
\hline $\begin{array}{c}\text { Lista } \\
\text { włoska }\end{array}$ & 33 & 65 & 98 & & \\
\hline $\begin{array}{c}\text { Lista } \\
\text { polska }\end{array}$ & 27 & 63 & 90 & & \\
\hline Komplety & 26 & 62 & 88 & 79 & 9 \\
\hline
\end{tabular}

\section{Analiza wyników}

Omawiane badania bazowały przede wszystkim na zagadnieniach: dwujęzyczności, dwukulturowości oraz teorii skojarzeń ze szczególnym naciskiem na teorię konekcjonistyczną.

\subsection{Zestawienie uzyskanych wyników}

Tabela 2 zawiera istotną część materiału badawczego. Jest to zbiór reakcji najczęstszych (tzw. pierwszych rang, czyli reakcji dominujących) w języku polskim i włoskim. Hasła przedstawiono według malejących wartości rangi pierwszej w liście polskiej. Kursywą wyszczególniono te hasła, które nie pochodzą z listy Kent-Rosanoffa. Oznaczono brak reakcji jako możliwą reakcję (po włosku: assente). Dodano również polskie tłumaczenia reakcji włoskich. 
Tabela 2. Zbiór reakcji najczęstszych (ranga I).

\begin{tabular}{|c|c|c|c|}
\hline Lp. & & I ranga $\mathrm{w}$ języku polskim & I ranga w języku włoskim \\
\hline \multirow[t]{2}{*}{1.} & chłopak / ragazzo & dziewczyna & ragazza / dziewczyna \\
\hline & & $40(45,45 \%)$ & $26(29,55 \%)$ \\
\hline \multirow[t]{2}{*}{2.} & tytoń / tabacco & papieros $(\mathrm{y})$ & sigaretta / papieros $(\mathrm{y})$ \\
\hline & & $40(45,45 \%)$ & $24(27,27 \%)$ \\
\hline \multirow[t]{2}{*}{3.} & wspólnie / insieme & razem & coppia / para \\
\hline & & $39(44,32 \%)$ & $11(12,5 \%)$ \\
\hline \multirow[t]{2}{*}{4.} & młotek / martello & gwóźdź(ie) & chiodo / gwóźdź(ie) \\
\hline & & $36(40,91 \%)$ & $23(26,14 \%)$ \\
\hline \multirow[t]{2}{*}{5.} & most / ponte & rzeka & fiume / rzeka \\
\hline & & $35(39,77 \%)$ & $42(47,73 \%)$ \\
\hline \multirow[t]{2}{*}{6.} & igła / ago & (z)(i) nitka & filo / nitka \\
\hline & & $34(38,64 \%)$ & $40(45,45 \%)$ \\
\hline \multirow[t]{2}{*}{7.} & godło / emblema & orzeł & segno / znak \\
\hline & & $33(37,5 \%)$ & $22(25 \%)$ \\
\hline \multirow[t]{2}{*}{8.} & powolny / lento & żółw & lumaca / ślimak \\
\hline & & $33(37,5 \%)$ & $30(34.09 \%)$ \\
\hline \multirow[t]{2}{*}{9.} & niebieski / blu & niebo & cielo / niebo \\
\hline & & $32(36,36 \%)$ & $35(39,77 \%)$ \\
\hline \multirow[t]{2}{*}{10.} & pachnący / odoroso & kwiat(y) & profumo / zapach \\
\hline & & $32(36,36 \%)$ & $30(34.09 \%)$ \\
\hline \multirow[t]{2}{*}{11.} & gwiazda / stella & niebo & cielo / niebo \\
\hline & & $31(35,23 \%)$ & $45(51,14 \%)$ \\
\hline \multirow[t]{2}{*}{12.} & kłopot / guaio & problem & problema / problem \\
\hline & & $31(35,23 \%)$ & $33(37,5 \%)$ \\
\hline \multirow[t]{2}{*}{13.} & płeć / sesso & kobieta & piacere / przyjemność \\
\hline & & $31(35,28 \%)$ & $18(20,45 \%)$ \\
\hline \multirow[t]{2}{*}{14.} & głosować / votare & wybory & elezioni / wybory \\
\hline & & $30(34,09 \%)$ & $32(36,36 \%)$ \\
\hline \multirow[t]{2}{*}{15.} & krótki / corto & długi & lungo / długi \\
\hline & & $30(34,09 \%)$ & $23(26,14 \%)$ \\
\hline \multirow[t]{2}{*}{16.} & ręka / mano & noga & dito / palec \\
\hline & & $30(34,09 \%)$ & $17(19,32 \%)$ \\
\hline \multirow[t]{2}{*}{17.} & gorzki / amaro & smak & dolce / słodki \\
\hline & & $29(32,95 \%)$ & $19(21,6 \%)$ \\
\hline \multirow[t]{2}{*}{18.} & zjednoczony / unito & $\operatorname{stan}(y)$ & insieme / wspólnie \\
\hline & & $29(32,95 \%)$ & $12(13,64 \%)$ \\
\hline \multirow[t]{2}{*}{19.} & ojciec / padre & matka & madre / matka \\
\hline & & $28(31,82 \%)$ & $37(42,01 \%)$ \\
\hline \multirow[t]{2}{*}{20.} & wysoki / alto & niski & basso / niski \\
\hline & & $28(31,82 \%)$ & $21(23,86 \%)$ \\
\hline \multirow[t]{2}{*}{21.} & solidarność / solidarietà & Wałęsa & amica / przyjaciółka \\
\hline & & $27(30,68 \%)$ & $8(9,09 \%)$ \\
\hline \multirow[t]{2}{*}{22.} & wystawa / mostra & obraz(y) (-ów) & quadro / obraz(y) (-ów) \\
\hline & & $26(29,55 \%)$ & $21(23,86 \%)$ \\
\hline \multirow[t]{2}{*}{23.} & rozkaz / comando & wojsko & ordine / porządek \\
\hline & & $25(28,41 \%)$ & $20(22,73 \%)$ \\
\hline 24. & marzyć / sognare & śnić & dormire / spać \\
\hline & & $24(27,27 \%)$ & $17(19,32 \%)$ \\
\hline
\end{tabular}




\begin{tabular}{|c|c|c|c|}
\hline 25. & ojczyzna / patria & Polska & Polonia / Polska \\
\hline & & $24(27,27 \%)$ & $28(31,82 \%)$ \\
\hline \multirow{2}{*}{26.} & piłka / palla & nożna & calcio / piłka nożna \\
\hline & & $24(27,27 \%)$ & $18(20,45 \%)$ \\
\hline \multirow[t]{2}{*}{27.} & zielony / verde & trawa & erba / trawa \\
\hline & & $24(27,27 \%)$ & $25(28,41 \%)$ \\
\hline \multirow[t]{2}{*}{28.} & zimny / freddo & lód & inverno / zima \\
\hline & & $24(27,27 \%)$ & $39(44,32 \%)$ \\
\hline \multirow[t]{2}{*}{29.} & czarny / nero & kot & bianco / biały \\
\hline & & $23(26,14 \%)$ & $26(29,55 \%)$ \\
\hline \multirow[t]{2}{*}{30.} & niebo / cielo & chmura(y) & azzuro / lazurowy \\
\hline & & $23(26,14 \%)$ & $18(20,45 \%)$ \\
\hline \multirow[t]{2}{*}{31.} & wojna / guerra & (i) pokój & pace / pokój \\
\hline & & $23(26,14 \%)$ & $11(12,5 \%)$ \\
\hline \multirow[t]{2}{*}{32.} & kibic / tifoso & mecz & calcio / piłka nożna \\
\hline & & $22(25 \%)$ & $33(37,5 \%)$ \\
\hline \multirow[t]{2}{*}{33.} & kobieta / donna & mężczyzna & uomo / mężczyzna \\
\hline & & $22(25 \%)$ & $28(31,82 \%)$ \\
\hline \multirow[t]{2}{*}{34.} & krzyż / croce & kościół & chiesa / kościół \\
\hline & & $22(25 \%)$ & $24(27,27 \%)$ \\
\hline \multirow[t]{2}{*}{35.} & makaron / pasta & Włochy & mangiare / jeść \\
\hline & & $22(25 \%)$ & $12(13,64 \%)$ \\
\hline \multirow[t]{2}{*}{36.} & anioł / angelo & stróż & bianco / biały \\
\hline & & $21(23,86 \%)$ & $11(12,5 \%)$ \\
\hline \multirow[t]{2}{*}{37.} & kolacja / cena & (przy) świeca (e) (ach) & mangiare / jeść \\
\hline & & $21(23,86 \%)$ & $13(14,77 \%)$ \\
\hline \multirow[t]{2}{*}{38.} & mistrz / campione & (i) Małgorzata & gara / wyścig \\
\hline & & $21(23,86 \%)$ & $11(12,5 \%)$ \\
\hline \multirow[t]{2}{*}{39.} & obraz / quadro & rama(y) & arte / sztuka \\
\hline & & $21(23,86 \%)$ & $18(20,45 \%)$ \\
\hline \multirow[t]{2}{*}{40.} & reklama / pubblicità & telewizja & $\mathrm{TV} / \mathrm{TV}$ \\
\hline & & $21(23,86 \%)$ & $16(18,18 \%)$ \\
\hline \multirow[t]{2}{*}{41.} & żółty / giallo & słońce & sole / słońce \\
\hline & & $21(23,86 \%)$ & $22(25 \%)$ \\
\hline \multirow[t]{2}{*}{42.} & pragnąć / desiderare & chcieć & volere / chcieć \\
\hline & & $20(22,73 \%)$ & $16(18,18 \%)$ \\
\hline \multirow[t]{2}{*}{43.} & radość / gioia & uśmiech & felicità / szczęście \\
\hline & & $20(22,73 \%)$ & $16(18,18 \%)$ \\
\hline \multirow[t]{2}{*}{44.} & szybki / veloce & samochód & macchina / samochód \\
\hline & & $20(22,73 \%)$ & $31(35,23 \%)$ \\
\hline \multirow[t]{2}{*}{45.} & dom / casa & rodzina & famiglia / rodzina \\
\hline & & $19(21,6 \%)$ & $25(28,41 \%)$ \\
\hline \multirow[t]{2}{*}{46.} & rodzina / famiglia & dom & amore / miłość \\
\hline & & $19(21,6 \%)$ & $12(13,64 \%)$ \\
\hline 47. & ser / formaggio & żółty & Parmiggiano / Parmezan \\
\hline & & $19(21,6 \%)$ & $10(11,36 \%)$ \\
\hline 48. & król / re & królowa & regina / królowa \\
\hline & & $18(20,45 \%)$ & $26(29,55 \%)$ \\
\hline 49. & lew / leone & król & re / król \\
\hline & & $18(20,45 \%)$ & $15(17,05 \%)$ \\
\hline 50. & lóżko / letto & sen & dormire / spać \\
\hline & & $18(20,45 \%)$ & $26(29,55 \%)$ \\
\hline
\end{tabular}


Michalina Lach, Michał Nowak: Skojarzenia słowne osób dwujęzycznych na podstawie języków: polskiego i włoskiego

\begin{tabular}{|c|c|c|c|}
\hline 51. & wynik / risultato & $\operatorname{mecz}(\mathrm{u})$ & $\begin{array}{c}\text { esame, effetto / egzamin, } \\
\text { efekt }\end{array}$ \\
\hline & & $18(20,45 \%)$ & $12(13,64 \%)$ \\
\hline \multirow[t]{2}{*}{52.} & ciemny / scuro & jasny & chiaro / jasny \\
\hline & & $17(19,32 \%)$ & $18(20,45 \%)$ \\
\hline \multirow[t]{2}{*}{53.} & okno / finestra & widok & aperta / otwarty \\
\hline & & $17(19,32 \%)$ & $13(14,77 \%)$ \\
\hline \multirow[t]{2}{*}{54.} & telewizor / televisore & film & film / film \\
\hline & & $17(19,32 \%)$ & $14(15,91 \%)$ \\
\hline \multirow[t]{2}{*}{55.} & zabytek / monumento & zamek & storia / historia \\
\hline & & $17(19,32 \%)$ & $11(12,5 \%)$ \\
\hline \multirow[t]{2}{*}{56.} & głęboki / profondo & dół & mare / morze \\
\hline & & $16(18,18 \%)$ & $20(22,73 \%)$ \\
\hline \multirow[t]{2}{*}{57.} & kultura / cultura & sztuka & arte / sztuka \\
\hline & & $16(18,18 \%)$ & $17(19,32 \%)$ \\
\hline \multirow[t]{2}{*}{58.} & piłkarz / calciatore & mecz & palla / piłka \\
\hline & & $16(18,18 \%)$ & $9(10,23 \%)$ \\
\hline \multirow[t]{2}{*}{59.} & rzeka / fiume & woda & acqua / woda \\
\hline & & $16(18,18 \%)$ & $19(21,6 \%)$ \\
\hline \multirow[t]{2}{*}{60.} & czerwony / rosso & krew & $\begin{array}{l}\text { sangue, fuoco / krew, } \\
\text { ogień }\end{array}$ \\
\hline & & $15(17,05 \%)$ & $11(12,5 \%)$ \\
\hline \multirow[t]{2}{*}{61.} & głodny / affamato & (jak) wilk & fame / głód \\
\hline & & $15(17,05 \%)$ & $9(10,23 \%)$ \\
\hline \multirow[t]{2}{*}{62.} & granica / frontiera & państwo (a) & paese / państwo \\
\hline & & $15(17,05 \%)$ & $10(11,36 \%)$ \\
\hline \multirow[t]{2}{*}{63.} & ocean / oceano & woda & mare / morze \\
\hline & & $15(17,05 \%)$ & $26(29,55 \%)$ \\
\hline \multirow[t]{2}{*}{64.} & wino / vino & czerwony & rosso / czerwony \\
\hline & & $15(17,05 \%)$ & $21(23,86 \%)$ \\
\hline \multirow[t]{2}{*}{65.} & wygoda / comodità & fotel & poltrona / fotel \\
\hline & & $15(17,05 \%)$ & $16(18,18 \%)$ \\
\hline \multirow[t]{2}{*}{66.} & gładki / liscio & skóra & capelli / włosy \\
\hline & & $14(15,91 \%)$ & $21(23,86 \%)$ \\
\hline \multirow[t]{2}{*}{67.} & jeść / mangiare & pić & bere / pić \\
\hline & & $14(15,91 \%)$ & $13(14,77 \%)$ \\
\hline \multirow[t]{2}{*}{68.} & krzesło / sedia & stół & tavolo / stół \\
\hline & & $14(15,91 \%)$ & $13(14,77 \%)$ \\
\hline \multirow[t]{2}{*}{69.} & twardy / duro & miękki, kamień & lavoro / praca \\
\hline & & $14(15,91 \%)$ & $13(14,77 \%)$ \\
\hline \multirow[t]{2}{*}{70.} & ulica / strada & $\operatorname{dom}(\mathrm{y})$ & macchina / samochód \\
\hline & & $14(15,91 \%)$ & $15(17,05 \%)$ \\
\hline \multirow[t]{2}{*}{71.} & wygrywać / vincere & przegrywać & gara / wyścig \\
\hline & & $14(15,9 \%)$ & $10(11,36 \%)$ \\
\hline \multirow[t]{2}{*}{72.} & ciężki / pesante & lekki & valigia / walizka \\
\hline & & $13(14,77 \%)$ & $14(15,9 \%)$ \\
\hline \multirow[t]{2}{*}{73.} & gwizdać / fischiare & mecz & $\begin{array}{l}\text { stadio, treno, assente / } \\
\text { stadion, pociąg, brak } \\
\text { reakcji }\end{array}$ \\
\hline & & $13(14,77 \%)$ & $5(5,68 \%)$ \\
\hline \multirow[t]{2}{*}{74.} & naród / nazione & Polska & popolo / naród \\
\hline & & $13(14,77 \%)$ & $13(14,77 \%)$ \\
\hline
\end{tabular}




\begin{tabular}{|c|c|c|c|}
\hline 75. & słońce / sole & ciepło & $\begin{array}{l}\text { caldo, spiaggia / gorący, } \\
\text { plaża }\end{array}$ \\
\hline & & $13(14,77 \%)$ & $13(14,77 \%)$ \\
\hline \multirow[t]{2}{*}{76.} & sztuka / arte & obraz(y) & quadro / obraz \\
\hline & & $13(14,77 \%)$ & $11(12,5 \%)$ \\
\hline \multirow[t]{2}{*}{77.} & chleb / pane & masło & cibo / jedzenie \\
\hline & & $12(13,64 \%)$ & $15(17,05 \%)$ \\
\hline \multirow[t]{2}{*}{78.} & pająk / ragno & sieć & paura / strach \\
\hline & & $12(13,64 \%)$ & $15(17,05 \%)$ \\
\hline \multirow[t]{2}{*}{79.} & praca / lavoro & pieniądze & soldi / pieniądze \\
\hline & & $12(13,64 \%)$ & $13(14,77 \%)$ \\
\hline \multirow[t]{2}{*}{80.} & rzeźbić / scolpire & sztuka & assente / brak reakcji \\
\hline & & $12(13,64 \%)$ & $15(17,05 \%)$ \\
\hline \multirow[t]{2}{*}{81.} & zdrowie / salute & choroba & malattia / choroba \\
\hline & & $12(13,64 \%)$ & $10(11,36 \%)$ \\
\hline \multirow[t]{2}{*}{82.} & instynkt / istinto & nagi & animale / zwierzę \\
\hline & & $11(12,5 \%)$ & $17(19,32 \%)$ \\
\hline \multirow[t]{2}{*}{83.} & miękki / morbido & poduszka & $\begin{array}{l}\text { duro, cuscino / twardy, } \\
\text { poduszka }\end{array}$ \\
\hline & & $11(12,5 \%)$ & $10(11,36 \%)$ \\
\hline \multirow[t]{2}{*}{84.} & owoce / frutta & warzywa & mela / jabłko \\
\hline & & $11(12,5 \%)$ & $20(22,73 \%)$ \\
\hline \multirow[t]{2}{*}{85.} & szorstki / ruvido & gładki & assente / brak reakcji \\
\hline & & $11(12,5 \%)$ & $22(25 \%)$ \\
\hline \multirow[t]{2}{*}{86.} & święty / santo & Mikołaj & $\begin{array}{l}\text { subito, papa (G.P.II) / } \\
\text { prędko, papież (J.P.II) }\end{array}$ \\
\hline & & $11(12,5 \%)$ & $12(13,64 \%)$ \\
\hline \multirow[t]{2}{*}{87.} & choroba / malattia & ból & morte / śmierć \\
\hline & & $10(11,36 \%)$ & $9(10,23 \%)$ \\
\hline \multirow[t]{2}{*}{88.} & drzwi / porta & dom & casa / dom \\
\hline & & $10(11,36 \%)$ & $23(26,14 \%)$ \\
\hline \multirow[t]{2}{*}{89.} & flaga / bandiera & maszt & paese / państwo \\
\hline & & $10(11,36 \%)$ & $12(13,64 \%)$ \\
\hline \multirow[t]{2}{*}{90.} & piękny / bello & brzydki & brutto / brzydki \\
\hline & & $10(11,36 \%)$ & $21(23,86 \%)$ \\
\hline \multirow[t]{2}{*}{91.} & ciało / corpo & obce & umano / ludzki \\
\hline & & $9(10,23 \%)$ & $19(21,6 \%)$ \\
\hline \multirow[t]{2}{*}{92.} & kawa / caffè & herbata, czarna(y) & espresso / espresso \\
\hline & & $9(10,23 \%)$ & $18(20,45 \%)$ \\
\hline \multirow[t]{2}{*}{93.} & miłość / amore & szczęście & felicità / szczęście \\
\hline & & $9(10,23 \%)$ & $16(18,18 \%)$ \\
\hline \multirow[t]{2}{*}{94.} & pamięć / memoria & wspomnienie(a) & ricordi / wspomnienie(a) \\
\hline & & $9(10,23 \%)$ & $10(11,36 \%)$ \\
\hline \multirow[t]{2}{*}{95.} & podłoga / pavimento & deska(i), parkiet & legno / drewno \\
\hline & & $9(10,23 \%)$ & $9(10,23 \%)$ \\
\hline \multirow[t]{2}{*}{96.} & złodziej / ladro & kradzież & rubare / kraść \\
\hline & & $9(10,23 \%)$ & $17(19,32 \%)$ \\
\hline \multirow[t]{2}{*}{97.} & złość / rabbia & gniew & $\begin{array}{l}\text { furia/ wściekłość; } \\
\text { namiętność }\end{array}$ \\
\hline & & $9(10,23 \%)$ & $8(9,09 \%)$ \\
\hline 98. & dziecko / bambino & małe & $\begin{array}{l}\text { piccolo, madre / małe, } \\
\text { matka }\end{array}$ \\
\hline
\end{tabular}


Michalina Lach, Michał Nowak: Skojarzenia słowne osób dwujęzycznych na podstawie języków: polskiego i włoskiego

\begin{tabular}{|c|c|c|c|}
\hline & & $8(9,09 \%)$ & $11(12,5 \%)$ \\
\hline 99. & grzech / peccato & pierworodny & religione / religia \\
\hline & & $8(9,09 \%)$ & $12(13,64 \%)$ \\
\hline 100. & kapusta / cavolo & bigos & verdura / warzywo \\
\hline & & $8(9,09 \%)$ & $11(12,5 \%)$ \\
\hline 101. & muzyka / musica & relaks & $\begin{array}{c}\text { radio, piacere / radio, } \\
\text { przyjemność }\end{array}$ \\
\hline & & $8(9,09 \%)$ & $7(7,95 \%)$ \\
\hline 102. & piwo / birra & kufel & $\begin{array}{c}\text { bicchiere, pub / } \\
\text { kieliszek/szklanka, pub }\end{array}$ \\
\hline & & $8(9,09 \%)$ & $7(7,95 \%)$ \\
\hline 103. & terroryzm / terrorismo & strach, USA & pericolo / zagrożenie \\
\hline & & $8(9,09 \%)$ & $39(44,32 \%)$ \\
\hline 104. & ziemia / terra & niebo, okragła & $\begin{array}{c}\text { cielo, pianeta / niebo, } \\
\text { planeta }\end{array}$ \\
\hline & & $8(9,1 \%)$ & $6(6,82 \%)$ \\
\hline 105. & motyl / farfalla & wiosna & $\begin{array}{c}\text { pasta, estate / makaron, } \\
\text { lato }\end{array}$ \\
\hline & & $7(7,95 \%)$ & $9(10,23 \%)$ \\
\hline 106. & sąsiad / vicino & dom & lontano / daleko \\
\hline & & $7(7,95 \%)$ & $31(35,23 \%)$ \\
\hline 107. & woda / acqua & życie, pragnienie & mare / morze \\
\hline & & $7(7,95 \%)$ & $13(14,77 \%)$ \\
\hline 108. & amator / dilettante & hobby, Kieślowski, aktor & assente / brak reakcji \\
\hline & & $4(4,55 \%)$ & $18(20,45 \%)$ \\
\hline
\end{tabular}

\subsection{Relacje paradygmatyczne i syntagmatyczne}

Dokonano charakterystyki uzyskanych haseł w randze pierwszej list polskiej i włoskiej ze względu na relacje leksykalne zachodzące między bodźcem a reakcją.

Relacje leksykalne podzielono na dwa zasadnicze rodzaje: relacje syntagmatyczne i relacje paradygmatyczne (meronimia, holonimia, hiperonimia, hiponimia, kohiponimia, synonimia, relacje opozycji - antonimia i komplenimia za: Miller, Beckwith, Fellbaum, Gross, Miller 1993; Bańczerowski, Pogonowski, Zgółka 1982; Lyons 1984; Derwojedowa, Karaś, Kopcińska 2005). Podział ograniczono do ww. kategorii. Miał on głównie za zadanie rzucić światło na powszechność występowania relacji syntagmatycznych i paradygmatycznych podczas udzielania odpowiedzi $\mathrm{w}$ języku polskim i języku włoskim, bez szczegółowego rozpatrywania rodzajów relacji.

Jeśli między bodźcem a reakcją nie zachodziła żadna relacja leksykalna z wymienionych powyżej, klasyfikowano taki przypadek jako: frazę (jeśli dana syntagma weszła już do języka jako stała struktura frazeologiczna), nazwę własną (zazwyczaj tytuł jakiegoś dzieła czy nazwa oficjalna), skojarzenie osobiste między bodźcem a reakcją (opatrzone komentarzem).

Poniższa tabela (nr 3) przedstawia wybrane przykłady bodźców wraz z odpowiadającymi im reakcjami rangi I z uwzględnieniem charakteryzujących daną parę relacji leksykalnych bądź kategorii pozostałych, takich jak: fraza, nazwa własna, czy skojarzenie osobiste.

Tabela 3. Charakterystyka relacji.

\begin{tabular}{|c|c|c|c|c|}
\hline Bodziec & $\begin{array}{c}\text { Reakcja }- \text { język } \\
\text { polski }\end{array}$ & $\begin{array}{c}\text { Charakterystyka } \\
\text { relacji }\end{array}$ & $\begin{array}{c}\text { Reakcja - język } \\
\text { włoski }\end{array}$ & $\begin{array}{c}\text { Charakterysytka } \\
\text { relacji }\end{array}$ \\
\hline chłopak / ragazzo & dziewczyna & komplenimia & $\begin{array}{c}\text { ragazza } \\
\text { (dziewczyna) }\end{array}$ & komplenimia \\
\hline tytoń / tabacco & papieros(y) & meronimia & $\begin{array}{c}\text { sigaretta } \\
\text { (papieros) }\end{array}$ & meronimia \\
\hline
\end{tabular}




\begin{tabular}{|c|c|c|c|c|}
\hline kłopot / guaio & problem & synonimia & $\begin{array}{c}\text { problema } \\
\text { (problem) }\end{array}$ & synonimia \\
\hline pachnący / odoroso & kwiat(y) & syntagma & $\begin{array}{c}\text { profumo } \\
\text { (perfumy, } \\
\text { zapach) }\end{array}$ & $\begin{array}{c}\text { skojarzenie } \\
\text { osobiste }\end{array}$ \\
\hline ręka / mano & noga & kohiponimia & dito (palec) & holonimia \\
\hline anioł / angelo & stróż & fraza & bianco (biały) & syntagma \\
\hline makaron / pasta & Włochy & nazwa własna & mangiare (jeść) & syntagma \\
\hline ciężki / pesante & lekki & antonimia & valigia (walizka) & syntagma \\
\hline owoce / frutta & warzywa & kohiponimia & mela (jabłko) & hiperonimia \\
\hline kapusta / cavolo & bigos & meronimia & $\begin{array}{c}\text { verdura } \\
\text { (warzywo) }\end{array}$ & hiponimia \\
\hline
\end{tabular}

Liczba relacji typu syntagmatycznego w języku polskim wyniosła 23, w języku włoskim 22, podczas gdy liczba relacji paradygmatycznych wynosiła odpowiednio 36 i 42 dla języka polskiego i włoskiego.

Tabela nr 4 przedstawia szczegółowe dane dotyczące liczby wystapień poszczególnych relacji lub ich braku w randze pierwszej list polskiej i włoskiej (w nawiasach podano procentowy udział tych relacji lub ich braku w puli udzielonych reakcji w każdym z języków). Dla 88 bodźców polskich uzyskano 116 reakcji dominujących (np. na bodziec „kawa” uzyskane reakcje dominujące: „herbata” i „czarna(y)” charakteryzowały się taką samą liczbą wystapień w ankietach) oraz dla 88 bodźców włoskich - 120 reakcji dominujących.

Tabela 4. Liczby i wartości procentowe poszczególnych typów reakcji.

\begin{tabular}{|c|c|c|}
\hline & JĘZYK POLSKI & JĘZYK WŁOSKI \\
\hline RELACJE & $23(19,83 \%)$ & $22(18,3 \%)$ \\
\hline SYNTAGMATYCZNE & $36(31,03 \%)$ & $42(35 \%)$ \\
\hline RELACJE & $3(2,59 \%)$ & $3(2,5 \%)$ \\
\hline meronimia & $6(5,17 \%)$ & $4(3,33 \%)$ \\
\hline holonimia & $2(1,72 \%)$ & $3(2,5 \%)$ \\
\hline hiperonimia & $0(0 \%)$ & $4(3,33 \%)$ \\
\hline hiponimia & $5(4,31 \%)$ & $3(2,5 \%)$ \\
\hline kohiponimia & $6(5,17 \%)$ & $9(7,5 \%)$ \\
\hline synonimia & $10(8,62 \%)$ & $42(10 \%)$ \\
\hline antonimia & $4(3,45 \%)$ & $4(3,33 \%)$ \\
\hline komplenimia & & $56(46,67 \%)$ \\
\hline BRAK RELACJI & $57(49,14 \%)$ & $120(100 \%)$ \\
\hline LEKSYKALNEJ & $116(100 \%)$ & \\
\hline RAZEM & &
\end{tabular}

Ogółem, w każdej z list większość relacji między bodźcem a reakcją należy do grupy relacji paradygmatycznych, czyli reakcje skojarzeniowe są homogeniczne $\mathrm{z}$ hasłem. Jest to typowe dla reakcji skojarzeniowych uzyskanych od osób dorosłych (por. Ciechanowicz 1975: 530). Spośród wszystkich relacji paradygmatycznych między bodźcem a reakcją najczęściej występuje w obu listach relacja opozycji (antonimia i komplenimia). Jest to również wynik typowy dla badań nad skojarzeniami werbalnymi osób dorosłych (por. Ciechanowicz 1975: 530).

$\mathrm{W}$ obu językach zaobserwowano przewage tendencji paradygmatycznej wobec tendencji syntagmatycznej, odpowiednio w języku polskim i włoskim - $36: 23$ oraz $42: 22$. Wydaje się, że rezultat ten potwierdza stałą tendencję występującą $\mathrm{w}$ badaniach skojarzeń słownych $\mathrm{w}$ wielu językach (por. Kurcz 1967b: 264). Mając jednak na uwadze możliwe rozbieżności w ustalaniu 
kryteriów podziału relacji podczas interpretacji wyników różnych badań skojarzeń słownych, należy liczyć się z brakiem możliwości ogólnego i miarodajnego porównania siły tendencji jednego rodzaju relacji.

Co więcej, język polski jako język syntetyczny sprzyja tworzeniu połączeń syntagmatycznych. Połączenia te to zazwyczaj mniej lub bardziej utarte określenia (por. Kurcz 1967b: 265). Można by się spodziewać, że respondenci będący mówcami natywnymi języka polskiego, obcującymi stale z tym językiem i kulturą polska, podczas podawania reakcji słownych w L1 wykażą silną tendencję syntagmatyczną. Zaobserwowano 23 takie połączenia. W porównaniu $\mathrm{z}$ wynikami listy włoskiej, rezultat ten nie wydaje się jednak znaczący. Wydawałoby się bowiem, że wśród wyników listy w języku włoskim, ze względu na mniej rozbudowaną fleksję i bardziej analityczny charakter języka, połączeń syntagmatycznych będzie mniej. Odnotowano 22 takie połączenia, czyli o jedno mniej niż w przypadku listy polskiej. Podobnie wygląda różnica wyników klasyfikowanych jako brak relacji leksykalnej w obu językach. Jak już wspomniano, za takie uważano frazy (potoczne stałe wyrażenia), nazwy własne (tytuły utworów, tytuły osób) oraz skojarzenia osobiste. W języku polskim uzyskano 57 takich przypadków, a w języku włoskim 56.

Należy jednak dodać, że wszelkie porównania liczbowe relacji leksykalnych w L1 i L2 w omawianych badaniach pozwalają tylko na ogólne zarysowanie problematyki i przyjrzenie się charakterowi występujących relacji. Jest to spowodowane przede wszystkim liczebnością próby respondentów (88 osób), jak również specyficznym charakterem badań skojarzeń werbalnych, w których respondentami są osoby dwujęzyczne, czyli mówcy natywni tylko jednego z języków, w których badania zostały przeprowadzone.

\subsection{Interpretacja wyników w aspekcie dwujęzyczności i dwukulturowości}

Pośród reakcji dominujących (ranga I) w języku polskim i języku włoskim zgodnych było 46, co stanowi 42,6 \% wszystkich haseł $\mathrm{w}$ randze I. (Za zgodne semantycznie uważano takie, które pojawiły się w I randze każdej z list mimo istnienia bądź braku w reakcji drugiego języka: przyimka, spójnika bądź tej samej liczby. Ponadto za takie same hasła w niniejszym porównaniu uznano reakcje „nożna” / „calcio” (w tłumaczeniu: piłka nożna) na bodźce „piłka” / „palla”.

Zestawienie zgodnych reakcji dominujących $\mathrm{w}$ obu językach wykazało, że 18 bodźców opartych na programie nauczania języka włoskiego w obu językach dało taką samą reakcję skojarzeniowa. Stanowi to 34, 62\% reakcji dominujących w języku polskim i języku włoskim na wszystkie bodźce sugerowane przez program nauczania. Pozostałe 28 zgodnych par bodźców i podanych haseł (bodziec - reakcja w j. polskim oraz bodziec - reakcja w j. włoskim) stanowi $50 \%$ odpowiedzi na bodźce z listy Kent-Rosanoffa.

Kurcz (1967b, s. 257) pisze, że „około połowy pierwszych najczęstszych skojarzeń w różnych językach jest równoważna tłumaczeniowo pod względem znaczenia”. Twierdzenie to jest wysunięte na podstawie prac porównawczych opartych na powszechności skojarzeń słownych na bodźce listy Kent-Rosanoffa wśród różnojęzycznych grup respondentów. Podobna sytuacja miała miejsce w przypadku omawianych tu badań mimo faktu, że ci sami respondenci udzielali odpowiedzi w dwóch znanych sobie językach - L1 i L2, a nie wyłącznie w języku pierwszym. Połowa pierwszych najczęstszych skojarzeń na bodźce listy Kent-Rosanoffa była zgodna thumaczeniowo w języku polskim i włoskim.

Wziąwszy pod uwagę specyfikę słownictwa opartego na programie nauczania, wyniki nie wydają się zaskakujące, przeciwnie, zdają się potwierdzać wstępne przypuszczenia. Powszechność słownictwa listy Kent-Rosanoffa prowadzi do uzyskania takich samych najczęstszych reakcji w obu językach (na połowę bodźców), podczas gdy słownictwo dotyczące poszczególnych dziedzin życia, jak również charakteryzujące się bogatszą treścią semantyczną, dało tylko jedną trzecią zgodnych odpowiedzi w randze pierwszej. Wynik ten sugeruje, że bodźce te postrzegane mogły być bardziej kulturowo, znaczy to, że reakcja słowna uzależniona była silniej od języka i kultury kraju języka, który był w danej chwili używany. Bodźce oparte na programie nauczania, jako bardziej szczegółowe, są również mniej powszechnie używane niż te z listy Kent-Rosanoffa. Uzasadniony wydaje się zatem wniosek, że bodźce rzadziej spotykane i o mniejszym zakresie oznaczania prowadzą do reakcji nacechowanych kulturowo, czyli do rozbieżności między reakcjami słownymi w różnych językach. 
Ranga pierwsza jako zbiór reakcji najczęstszych stanowi dobry materiał do analizy potencjalnych różnic $\mathrm{w}$ postrzeganiu rzeczywistości wypływających $\mathrm{z}$ użycia innego języka. Udzielenie odpowiedzi nacechowanych kulturowo zdeterminowane było językiem, w którym były one podawane. Nacechowanie to było na tyle silne, że mimo swojej specyfiki były one najczęstsza reakcją respondentów na dany bodziec. Należy przy tym mieć na uwadze, że respondentami były osoby dwujęzyczne, a zatem, głównie poprzez naukę języka drugiego, były one wystawione na działanie pewnych czynników kulturowych, które mogły wpłynąc na ich stereotypy skojarzeniowe w L2.

Poniżej, spośród reakcji rangi I wybrano te, które świadczyć mogą o uzależnieniu postrzegania świata zewnętrznego od języka używanego przez mówcę w danej chwili. )Opisywane badania zostały przeprowadzone z udziałem studentów filologii włoskiej. A zatem zarówno ich wiek, doświadczenia, jak i zainteresowania znalazły odbicie w podawanych przez nich reakcjach na bodźce słowne. Tabela 5 (oraz kolejne) zbudowana jest $\mathrm{z}$ trzech kolumn, z których pierwsza zawiera bodziec polski i jego tłumaczenie włoskie, a kolejne dwie - reakcje dominujące na dane bodźce.

Tabela 5. Wybrane pary bodziec - reakcja dla obu języków.

\begin{tabular}{|c|c|c|}
\hline ser / formaggio (1) & żółty & Parmiggiano / Parmezan \\
\hline głęboki / profondo (2) & dół & mare / morze \\
\hline chleb / pane (3) & masło & cibo / jedzenie \\
\hline kapusta / cavolo (4) & bigos & verdura / warzywo \\
\hline woda / acqua(5) & życie, pragnienie & mare / morze \\
\hline kawa / caffè (6) & herbata, czarna(y) & espresso / espresso \\
\hline słońce / sole (7) & ciepło & $\begin{array}{c}\text { caldo, spiaggia / gorący, } \\
\text { plaża }\end{array}$ \\
\hline wynik / risultato (8) & mecz(u) & $\begin{array}{c}\text { esame, effetto / egzamin, } \\
\text { efekt }\end{array}$ \\
\hline
\end{tabular}

Na bodziec „ser / formaggio” (1) reagowano typowym dla kultury i języka polskiego skojarzeniem „żółty”, jako że w kulturze polskiej nie przywiązuje się dużej wagi do nazw typów sera. Najczęstszą reakcją w języku włoskim natomiast był właśnie typ sera 'Parmiggiano'. Reakcja ta jest wysoce nieprawdopodobna w przypadku języka polskiego.

„Głęboki / profondo” (2) w języku polskim wywołuje ogólne skojarzenie „dół”, podczas gdy w języku włoskim reakcją było „mare” (morze), które posiada silne znaczenie dla kultury i położenia geograficznego Włoch. Podobnie bodziec „acqua” (5) (woda) w języku włoskim kojarzy się najsilniej z „mare”, w przeciwieństwie do języka polskiego, gdzie „woda” utożsamiana jest głównie z ,życiem, pragnieniem”.

„Chleb” (3) z „masłem” stanowi charakterystyczny przykład stereotypowego śniadania polskiego. Natomiast w kulturze włoskiej ,pane” (chleb) często stanowi dodatek do obiadu, a jednocześnie zdaje się nie mieć tak silnie utrwalonej pozycji w kuchni włoskiej, dlatego kojarzony jest ogólnie jako ,jedzenie”.

„Kapusta” (4) jest głównym składnikiem typowego dania kuchni polskiej - „bigosu”, podczas gdy w kulturze włoskiej stanowi przykład warzywa. („Bigos” nie znajduje również swojego bezpośredniego ekwiwalentu tłumaczeniowego w języku włoskim. Wg Podręcznego słownika polsko-włoskiego (2001) „,bigos” to „piatto di crauti e pezzi di salsicce”, czyli „danie z kapusty i kawałków kiełbasy”. Warto jednak zauważyć, że „bigos” pojawia się jako reakcja indywidualna na bodziec „cavolo” listy włoskiej).

„Kawa” (6) w języku polskim nasuwa skojarzenie innego napoju - „herbaty”. W Polsce gospodarz często zadaje gościom pytanie „,kawa czy herbata?”. Co więcej, „Kawa czy herbata” jest nazwą programu w Telewizji Polskiej. W Polsce dzieli się również kawę na czarną i białą (z mlekiem). Natomiast w języku włoskim i w kulturze Włoch występuje dużo bardziej szczegółowy podział na typy kawy, z czego „espresso” jest chyba najbardziej popularnym i utożsamianym z Włochami. 
Bodziec „słońce” (7) w randze pierwszej listy polskiej przywodzi na myśl jedynie związaną z nim cechę „ciepła”. Użycie języka włoskiego sugeruje spojrzenie na bodziec przez pryzmat kultury włoskiej i klimatu tego obszaru językowego, co w rezultacie daje reakcje dominujące „caldo” (gorący) i „spiaggia” (plaża).

Innym ciekawym przykładem różnic, tym razem uzależnionych od sytuacji życiowej respondentów, jest bodziec „wynik / risultato” (8) i reakcje rangi pierwszej w języku polskim i włoskim. Tak jak w pierwszym z nich reakcją jest „mecz(u)”, tak w drugim języku reakcjami najpowszechniejszymi są „esame” (egzamin) oraz „efetto" (efekt). Powodem tego może być doświadczenie studentów, którzy zdając egzaminy w języku włoskim i dążąc do uzyskania najlepszych efektów na studiach, kojarzą bodziec „risultato” właśnie z własną nauką na uczelni.

\subsection{Występowanie nazw własnych}

Poniższa tabela (Tabela 6) pokazuje, dla jakich haseł odpowiedzi o randze I stanowią nazwy własne. Co ciekawe, nazwy własne pojawiają się wyłącznie jako reakcje na hasła-bodźce oparte na programie nauczania języka włoskiego. W założeniu, są to bodźce mniej powszechne, a jednocześnie silniej nacechowane kulturowo.

Tabela 6. Nazwy własne.

\begin{tabular}{|c|c|c|}
\hline ojczyzna / patria & Polska & Polonia / Polska \\
\hline naród / nazione & Polska & popolo / naród \\
\hline solidarność / solidarieta & Wałęsa & amica / przyjaciółka \\
\hline makaron / pasta & Włochy & mangiare / jeść \\
\hline święty / santo & Mikołaj & $\begin{array}{c}\text { subito, papa (G.P.II) / prędko, } \\
\text { papież (J.P.II) }\end{array}$ \\
\hline terroryzm / terrorismo & strach, USA & pericolo / zagrożenie \\
\hline amator / dilettante & hobby, Kieślowski, aktor & assente / brak reakcji \\
\hline instynkt / istinto & nagi & animale / zwierzę \\
\hline mistrz / campione & (i) Małgorzata & gara / wyścig \\
\hline wojna / guerra & (i) pokój & pace / pokój \\
\hline
\end{tabular}

Co ciekawe, nazwy własne rzadko występowały jako reakcje na dany bodziec zarówno w języku polskim jak i w języku włoskim. Świadczy to o silnej zależności danej reakcji od używanego języka. W randze pierwszej nie było sytuacji, w której nazwa własna wystapiłaby jako reakcja na dany bodziec $\mathrm{w}$ języku włoskim, a jednocześnie nie pojawiłaby się $\mathrm{w}$ reakcji na odpowiadający mu bodziec polski.

Przedstawione pokrótce wyniki ankiet sugerują istnienie wspomnianego wyżej zjawiska Cultural Frame Switching, jako że język używany przez respondentów (L1 bądź L2) wpływał na przywołanie właściwych kulturze danego języka skojarzeń, wartości czy wspomnień. Z pewnością dużą zasługę w uzyskaniu takiego wyniku można przypisać kształceniu kulturowemu niezbędnemu na studiach językowych, gdzie celem jest osiagnięcie biegłości w języku obcym (L2), jak również uzyskanie rzetelnej i szerokiej wiedzy na temat obcej kultury (LC2).

\subsection{Interpretacja wyników w aspekcie leksykonu umysłowego}

Należy zaznaczyć, że tak jak skojarzenia należące do najwyższych rang (najczęstsze) moga stanowić o pewnych tendencjach, schematach czy normach asocjacyjnych, analiza wyników badań poświęconych dostępowi leksykalnemu skupia się na nieco innym aspekcie takich eksperymentów. Reakcje zawierające się w pierwszych rangach mogą świadczyć o ogólnym charakterze reakcji dla danej grupy, niejako o jej profilu. Natomiast reakcje indywidualne, jak również te mieszczące się w niższych rangach - bardzo często charakteryzujące się oryginalnością - sugerują istnienie wielu rodzajów połączeń wyrazowych. A więc nie tylko takich, które opierają się na relacjach leksykalnych, ale również takich, które mogą tworzyć związki jedynie w sferze pojęciowej, na poziomie znaczeń. Zagadnienie to staje się znacznie bardziej złożone w przypadku skojarzeń osoby dwujęzycznej, szczególnie w zakresie skojarzeń w L2. Mówi się tutaj o leksykonie osoby 
dwujęzycznej, czyli o leksykonie o większej objętości - bo zawierającej dodatkowy zbiór leksemów odnoszących się do już istniejących znaczeń. Co więcej, jak wiadomo, w przypadku dwujęzyczności można mówić o istnieniu szerszego niż w przypadku osób jednojęzycznych systemu pojęć. Niewątpliwym tego przykładem są te hasła z listy, których znaczenia nieco różnią się w obydwu językach. Tym niemniej, hasła te pozostają najbliższymi odpowiednikami. Przykłady takie jak: „sąsiad” (it: „,vicino”), „kapusta” (it: „,cavolo”), czy „żółty” (it: „giallo”) stanowią podbudowę twierdzeń o dwóch poziomach: leksykalnym i znaczeniowym. Jak się okazuje, różnice, choć nie tak wyraźnie zarysowane jak w przypadku samej leksyki, pojawiają się również na poziomie znaczeniowym. Słowo „vicino”, oprócz polskiego „sąsiad”, oznacza również przysłówek „blisko”; „cavolo” jest włoskim odpowiednikiem nazwy warzywa, ale ma też drugie znaczenie jest włoskim wulgaryzmem; natomiast wspomniany wcześniej „giallo” (włoski odpowiednik nazwy koloru „żółty”) jest częścią związku frazeologicznego: „film giallo”, określanego w języku polskim jako „film grozy”. Różnice te nie pozostają bez znaczenia dla mechanizmów skojarzeniowych.

Kwestia poziomu znaczeniowego dotyczy również pewnego specyficznego typu relacji, mianowicie: relacji meronimii (cząstkowości). W niniejszej pracy, relacja meronimii została zaklasyfikowana do zbioru relacji leksykalnych (dokładniej: paradygmatycznych), a więc opierających się przede wszystkim na związkach w warstwie leksykalnej. Tymczasem, trudno jest zaklasyfikować parę bodźców podłoga - deski jako relację czysto paradygmatyczną. Niewątpliwie opiera się ona również na połączeniach spoza grupy relacji tego typu. Mamy tu do czynienia $\mathrm{z}$ odwołaniem się do definicji pojęcia „podłoga” (np. do faktu, że nierzadko wykonana jest ona właśnie z desek), a więc mowa tu o warstwie semantycznej - czyli relacji pomiędzy znakiem a przedmiotem.

Wspomniany tu model konekcjonistyczny zakłada istnienie sieci połączeń między poszczególnymi węzłami łącząc je w morfemy, sylaby, leksemy i inne jednostki składające się na cały system zwany leksykonem umysłowym. Omawiane badania ukazują, jak wiele z założeń tego nurtu znajduje swoje odniesienie w rzeczywistości - mimo że grupa osób badanych nie była zbyt liczna.

Zgodnie z założeniami konekcjonizmu, skojarzenia słowne są tym silniej utrwalone w pamięci im większa jest grupa leksemów, z którymi się one łączą. Innymi słowy, im więcej jest różnych możliwych kontekstów, w których dane słowo może wystapić, tym bardziej wzrasta prawdopodobieństwo, że leksem ten będzie miał szerokie spektrum różnych asocjacji. Może on zatem być określony mianem słowa potocznego, często używanego, powszechnego. Właśnie takie wyrazy mają najwięcej skojarzeń i dla takich wyrazów można spodziewać się wystąpienia zbioru reakcji najczęstszych - zależnie od charakteru grupy respondentów, ich kultury i subkultury, z jakiej się wywodzą - charakteryzującego się pewnymi określonymi cechami.

Analiza rang pierwszych wyników omawianych w niniejszej publikacji badań - niezależnie od języka - dostarcza dodatkowych informacji na temat charakteru dostępu leksykalnego. Wspomniane wcześniej zbiory par: bodziec - reakcja, które zostały zakwalifikowane do grupy „nieposiadającej relacji leksykalnej” stanowią odpowiednio dla ankiet w języku polskim i włoskim: $49,14 \%$ i 46,67\% wszystkich reakcji z tej rangi. Jest to dość znaczący wynik (w obu przypadkach). Świadczyć on może bowiem o wadze skojarzeń opierających się w głównej mierze na połączeniach na poziomie znaczeniowym, popierając tym samym tezę o sieci skojarzeń różnego typu - w tym również tzw. „,pod-sieci”. Należy tu przypomnieć, że model konekcjonistyczny zakładał istnienie połączeń nie tylko między poszczególnymi jednostkami leksykonu umysłowego, ale również między całymi sieciami takich połączeń, a więc zarówno między całymi polami semantycznymi, jak i między tymi polami a sieciami odpowiedzialnymi za przenoszenie znaczeń. Na tej podstawie można wysunąć wniosek, że mechanizmy skojarzeniowe nie opierają się tylko na jednym rodzaju relacji. Przykład stanowić mogą problematyczne w ocenie rodzaju relacji związki frazeologiczne. Mogą one być traktowane jako zbiory leksemów, które nabierają zupełnie innego znaczenia, jeśli zestawimy je w odpowiednie grupy (np. idiomy). Frazeologizmy mogą być również traktowane jako oddzielne, nieco większe, jednostki słownika umysłowego. Mowa więc tu o relacji bardzo złożonej, opartej zarówno na związkach czysto leksykalnych, jak i na tych odwołujących się do warstwy znaczeniowej. 
Sytuacja przedstawia się podobnie w przypadku skojarzeń indywidualnych. Mowa tu zarówno o reakcjach pozostających w pewnym związku semantycznym z samym bodźcem - niezależnie od tego, czy jest to relacja typu paradygmatycznego czy syntagmatycznego - jak i reakcjach należących do grupy bardzo oryginalnych, wyszukanych, np.: gładki - jezioro, słońce - Kopernik, istinto - Sharon Stone (instynkt - Sharon Stone), patria - bianco e rosso (ojczyzna - biały i czerwony). Istnieje kilka możliwych wyjaśnień pojawienia się takich reakcji. Jednym z nich jest założenie, że respondent podający taką reakcję nie kieruje się swoim pierwszym wolnym skojarzeniem i celowo podaje reakcję bardziej wyszukaną. Inną przyczyną może być fakt posiadania przez respondenta pewnych osobistych przeżyć, które mają wpływ na reakcje na określone bodźce - np. wspomnienia z dzieciństwa, ostatnio widziany film czy sytuacja z życia codziennego. Niezależnie od przyczyn należy jednak zauważyć, że reakcje te nie podlegają podziałom stricte językowym, a więc są za nie odpowiedzialne inne mechanizmy (połączenia), obejmujące poziom zarówno leksykalny, jak i znaczeniowy.

Dodatkowo, w przypadku reakcji indywidualnych oraz tych z niższych rang mamy do czynienia ze zjawiskiem tzw. 'clang-responses', czyli reakcji związanych z bodźcem jedynie na podstawie podobieństwa fonetycznego. Jest to o tyle ciekawe, że ankiety wypełniane były na zasadzie czytania hasła i wpisywania obok niego pierwszego skojarzenia. Świadczyć to może zatem o przetwarzaniu bodźca nie tylko w zakresie jego cech semantycznych, ale również jego kształtu fonetycznego. Przykładami takich reakcji mogą być: grzech - trzech, wojna - bogobojna, słońce - końce, nazione - azione (naród - aktywność, działalność), emblema - problema (godło problem), letto - tetto (łóżko - dach). Wystapiły one jednak niezwykle rzadko i w zbliżonej liczbie dla obu list. Mimo to, sugerować to może istnienie takich połączeń między leksemami, które związane są tylko z ich kształtem fonetycznym. Co więcej, połączenia te - choć rzadkie - są również $\mathrm{w}$ jakimś stopniu utrwalone, bo przecież zostały aktywowane stając się reakcjami na bodźce werbalne.

\section{Podsumowanie}

Pomimo relatywnie niewielkiej grupy respondentów, zaobserwowano pewne zależności między skojarzeniami w języku włoskim i w języku polskim. Grupę respondentów stanowiły osoby pochodzenia polskiego, których - domniemanym na podstawie kierunku studiów - językiem L2 jest język włoski. Wyniki badań ukazały zależności między postrzeganiem świata przez pryzmat zarówno języka ojczystego, jak i obcego. Otóż najczęstsze skojarzenia dla obu języków na słowabodźce będące w większości bardzo ścisłym tłumaczeniem okazały się bardzo zbliżone - jeżeli nie były to odpowiedniki, to na pewno mieściły się one w tym samym polu semantycznym. Również analiza reakcji indywidualnych potwierdziła tę obserwację - charakter grup reakcji indywidualnych na poszczególne bodźce nie różnił się znacznie w obrębie obu języków.

Ponadto, reakcje na hasła dodatkowe ukazały szereg zależności między nauką języka L2, a nabywaniem kultury obszaru językowego tego języka. Co ważne, mowa tu przede wszystkim o skojarzeniach pozajęzykowych. Podejście konekcjonistyczne wykorzystane w niniejszej publikacji w ramach opisu dostępu leksykalnego może mieć swoje odniesienie w wynikach badań. Zarówno język L1 i L2 stanowią bowiem część sieci połączeń między elementami pamięci nie tylko związanymi właśnie z językiem, ale również z elementami pozajęzykowymi. 


\section{Bibliografia}

Bańczerowski J., Pogonowski J., Zgółka T. 1982. Wstęp do językoznawstwa. Poznań: Wydawnictwo Naukowe UAM.

Ciechanowicz A. 1975. Swobodne skojarzenia słowne. Przegląd literatury, Psychologia Wychowawcza 4, 520-533.

Czykwin E., Misiejuk D. 2002. Dwujęzyczność i dwukulturowość w perspektywie psychopedagogicznej. Białystok: Trans Humana.

Derwojedowa M., Karaś H., Kopcińska D. red. 2005. Język polski. Kompendium. Warszawa: Świat Książki.

Gleason J.B., Ratner N.B. red. 2005. Psycholingwistyka. Gdańsk: GWP.

Korshuk A. 2004. Earning more about cultures through free word association data. (http://www.immi.se/intercultural/nr8/ korshuk.htm) 2007.

Kurcz I. 1967a. Polskie normy powszechności skojarzeń swobodnych na 100 słów z list Kent-Rosanoffa, Studia Psychologiczne, t. VIII, 122-127.

Kurcz I. 1967b. Porównanie powszechności skojarzeń w różnojęzycznych grupach studenckich, Studia Psychologiczne, t. VIII, 256-271.

Lyons J. 1984. Semantyka. Warszawa: Państwowe Wydawnictwo Naukowe. Tom 1.

Łobacz P., Mikołajczak-Matyja N. 2002. Skojarzenia stowne w psycholeksykologii i onomastyce psycholingwistycznej. Poznań: Sorus.

Mikołajczak-Matyja N. 2004. Skojarzenia słowne niewidomych i widzących użytkowników języka polskiego - studium porównawcze. Investigationes Linguisticae, vol. XI, Poznań: Instytut Językoznawstwa, 1-17.

Miller G.A., Beckwith R., Fellbaum Ch., Gross D., Miller K. 1993. Introduction to WordNet: An On-line Lexical Database.

Ramirez-Esperanza N., Gosling S.D., Benet-Martinez V., Potter J.P., Pennebaker J.W. 2006. Do bilinguals have two personalities? A special case of cultural frame switching. Journal of Research in Personality 40, 99-120

Rosenzweig M.1961a. Comparison among word-association responses in English, German, and Italian. Amer. Jour. Psychol., 74, 347-373.

Scheu D. 2000. Cultural constraints in bilinguals' codeswitching. International Journal of Intercultural Relations 24, 131-150.

Schmitt N. 1998. Quantifying word association responses: what is native-like? System 26, 389-401.

Waring, R. 1996. Connectionism and Second Language Vocabulary. (http://www1.harenet.ne.jp/ waring/papers/ connect.html) 2007.

Wolter B. 2002. Assessing proficiency through word associations: is there still hope? System 30, 315-329.

\section{Slowniki:}

Meisels W. 2001 Podręczny stownik włosko-polski. Warszawa: Wiedza Powszechna. Meisels W. 2001. Podręczny stownik polsko-wtoski. Warszawa: Wiedza Powszechna. 